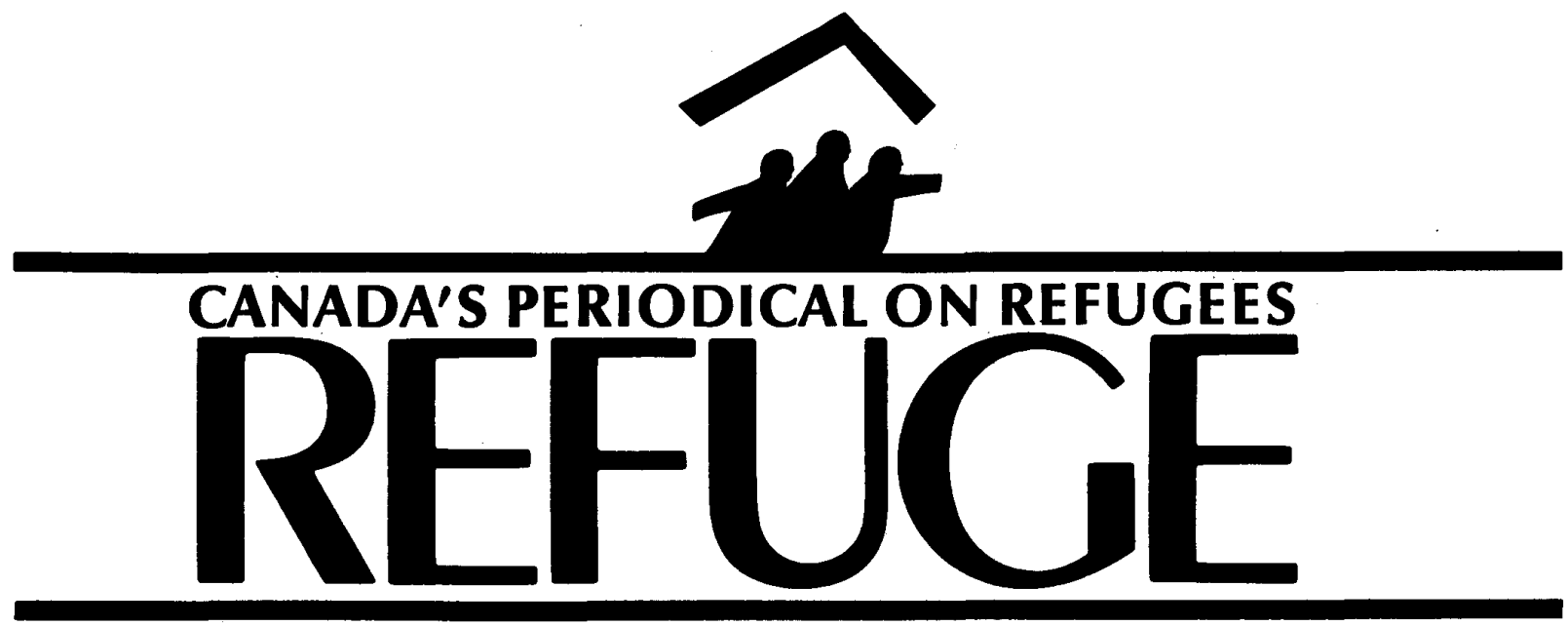

\title{
American Indochinese Refugees: Are They Welfare Bums?
}

Studies of refugees are an excellent vantage point to gain an insight into the political life, economic policies and values of society.* Studies of studies of refugees provide a shortcut to the same goal. A report of the Appropriations Committee of the U.S. House of Representatives argues that $67 \%$ of the Indochinese refugees settled in the United States have become dependent on the state. The source of the problem is public welfare and its partner, a poor bureaucracy which provides ineffective management, direction and administration for the refugee assistance program.

"Even though there has been a heavy commitment of funds, resources, and personnel at the Federal, State, and local government levels, the refugee assistance programs have not succeeded in their basic objective of decreasing the level of dependency of refugees participating in the programs. In fact, the dependency rate or percentage of the refugee population receiving cash assistance and other benefits has steadily increased since 1975, the year the Indochinese Refugee Assistance Program was initiated. As of June 1981, the nationwide dependency rate reported by the Office of Refugee Resettlement (ORR) was 67\% and growing. For FY 1983, ORR is predicting a nationwide dependency rate of $70 \% . "$

This is a shocking conclusion for Canadians who take great pride in the way Indochinese refugees in Canada have adapted so well in spite of a severe downturn in the economy which has affected them disproportionately. But before one asks why the Indochinese refugees have fared so poorly in the U.S., one must ask first if it is true.

The report draws even more drastic conclusions. The refugees are developing a welfare mentality.

"What is even more worrisome than the immediate dismal situation are indications that a strong 'constituency' is being formed among refugees which expects continued assistance over a prolonged period of time. Most of the aid recipients are being nurtured so that all their wants are being catered to without much work, effort, or sacrifice on their part. Thus, a philosophy or attitude is being engendered - directly and indirectly - that they have a vested right, entitlement, if you will, to: money, housing food, clothing medical attention, and educational allowances from Federal, State, and local government sources."

What are the facts? Can you measure dependency?

One method entails comparing refugee resettlement expenditures in different - See Page 2. Indochinese Refugee Social Assistance Programs in Europe and the United States. jurisdictions. (Fortunately, the European report, though weak on assessment, evaluation and policy recommendations, has excellent basic data) The Netherlands, for example, spent Fl.32,000 (U.S.\$11,500 approx.) per refugee for help and resettlement. The average cost of resettlement per refugee in the U.S.A. was less than one-tenth that figure (\$936.00), including cash allowances for resettlement, medicare and social service costs. In Canada, the cost of resettlement per refugee was U.S.\$4,100 if all costs are considered. For direct social assistance, the cost per refugee was in the order of U.S.\$2,100.

If Americans spend so little to resettle each refugee, how can this be reconciled with the claim that $67 \%$ are dependent on the state? The report, unfortunately, never defines dependency. However, one can tease out its meaning by reading the whole report. The contrast with Cont. on page 3

\section{ALSO FEATURED IN THIS ISSUE . . . . . . . . . . . .}

FACT FINDING VISIT TO CENTRAL AMERICA:

excerpts from the Dawson Report $\ldots \ldots \ldots \ldots \ldots \ldots \ldots \ldots \ldots \ldots \ldots \ldots, 7$

With a commentary by Professor Meyer Brownstone $\ldots \ldots \ldots \ldots \ldots \ldots \ldots 8$

HUMAN RIGHTS AND MASSIVE EXODUS the Aga Khan Report

INTERNATIONAL PROTECTION: a report on

the UNHCR Executive Committee Meeting ..................... 


\section{REFUGE}

c/o Refugee Documentation Project York University, 4700 Keele Street, Downsview, Ontario M3J $2 R 6$

\section{Editor:}

Howard Adelman

Managing Editor:

Caroline Stephens

Editorial Board:

Douglas Cohen, Montreal

Claudio Duran, Toronto

Arie van Eek, Burlington

Donald Ferguson, Toronto

James Hathaway, Moncton

Michael Pitman, Toronto

Linda Weigl, Regina

Typesetting and Layout:

\section{Seagull Graphics Inc.}

Refuge is dedicated to encouraging assistance to refugees, by providing a forum for sharing information and opinion on Canadian and international issues pertaining to refugees. It is published five times a year, in October, December, February, April and June. It is a non-profit, independent periodical supported by grants from the Canadian Foundation for Refugees Operation Lifeline, and the Canada Employment and Immigration Commission; by private donations; and by subscription payments of $\$ 10$ a year. It is a forum for discussion, and the views expressed do not necessarily reflect those of its funders, staff or Editorial Board.

All material in Refuge may be reproduced without permission unless copyrighted or otherwise indicated. Credit should be given to the author or source if named.

Logo design:

Dreadnaught Cooperative Inc. Toronto

Second Class Mail Registration No. 5512 ISSNO229-5113

\section{Correction}

In the Note on the Politics of Counting the World's Refugees (page 12, Sept. - Oct., 82 Refuge), the fifth sentence should read, "The number of Palestinian refugees does include children of refugees ..."

\section{Letters}

\section{To the Editor:}

We have just recently received the September/October issue of Refuge ànd read with a great deal of interest, your open letter to The Honourable Lloyd Axworthy.

We wish to commend you for your efforts and want you to know that we will support and assist you whenever possible.

Audrey Johnson, RSW

Coordinator,

Nanaimo Refugee Coordination

Society

(See following letter)

\section{Indochinese Refugee Social Assistance Programs in Europe and the United States}

One of the important functions of Refuge is the analysis and interpretation of key reports on refugees. In the last issue, we informed readers of three important studies on the resettlement of the Indochinese in Canada. In this issue we compare three reports, two American and one European, which analyze the assistance offered in refugee resettlement.

In July of 1982, the Council of Europe, through its Steering Committee for Social Affairs (CDSO), published a report by consultant Reinhard Lohrmann, who is the chief of the Research and Documentation Unit for the Department of Planning, Liaison and Research of the Intergovernmental Committee for Migration (ICM) in Geneva. The report deals with the social situation and social measures concerning people seeking political asylum or having refugee status in the member states of the Council of Europe.

A "Profile of the State Refugee Resettlement Programs" (undated) prepared by the Office of State Services of the National Governors' Association on the basis of surveys conducted during the 1980-81 fiscal year is very similar to the European report. Both compare data from different jurisdictions (independent nation states in the Council of Europe; states in the American union). Each reflects the preoccupation of the different perspectives. Both reports begin with the customary background material and numerical comparisons of the different jurisdictions, then each diverges. Given the different problems - America, a federal state with divided jurisdictions, relies much

Dear Mr. Axworthy:

We are responding to a recent press release that the number of immigrants to Canada will be reduced.

We accept the logic of reducing the number of immigrants at this time when our country is unable to provide employment to its citizens but we believe Canada would be evading its duty more if we close our doors to the hapless refugee who faces a life of utter hopelessness until we extend a helping hand. We therefore ask that the refugee portion of the immigrant quota not be reduced in spite of bad economy.

We also suggest that the government might relieve the public pressure by once again suggesting to individual Canadians that they can sponsor refugees.

Turning to another facet of immigration, we ask that Canadian officials involved in more on the non-governmental sector than Europe - it is not surprising to find the Governors', report concentrating almost entirely on problems of administration and coordination.

The European report concentrates on the actual social measures provided for the refugees - reception centres, housing, resettlement patterns, social assistance, language training, education, health, secondary migration and family reunification. These are more or less the same topics dealt with in the Second American report prepared in February focussing on the refugee assistance program of the Office of Refugee Resettlement (ORR) of the Department of Health and Human Services. Unfortunately, this American report was not written by an independent consultant with a knowledge of and experience in refugee matters, but by the surveys and investigations staff of the Committee of Appropriations of the U.S. House of Representatives. The lack of independence and expertise in this case is combined with such poor social science methodology and such illogical reasoning wrapped up in tendentious moralizing that the result tells us more about the political attitudes of the authors and, perhaps, about the U.S. government than about refugee assistance programs for the Indochinese. The feature article in this issue takes the Congressional Report as its centrepiece and uses the European report and the Governors' report as a Greek chorus from which comments and insights can be gained into one policy direction active in the U.S. government

counselling normal immigrants, and perhaps even those refugees who might have a further option, acquaint these people with the realities of life in Canada. It would appear that many have unrealistic expectations.

If potential newcomers have the hurdles and alternatives clearly set out for them by Immigration counsellors at the time of interview, then many decisions made about coming to Canada clearly become their own responsibility and no blame can be laid at the door of the Canadian government.

Our concerns have evolved from our frequent and direct contact with these new immigrants.

David L. Handley President.

Nanaimo Refugee Coordination Society 


\section{Cont. from page 1}

dependency is total self-sufficiency. Any refugee who receives state cash assistance of any kind is not self-sufficient and therefore dependent. On that definition, all families in Canada with children under 18 would be classified as dependent After all, they receive state monies in the form of family allowances and, hence, are not totally self-sufficient. A student and his family are dependent on the state if that student receives an educational grant. Since Canadians enjoy the benefits of medicare, the authors of the report, using their logic, would conclude that Canadian "wants are being catered to without much work, effort and sacrifice on our part."

The issue is not that Indochinese refugees resettled in the U.S. are more dependent than the refugees who settled in Canada, but that a number of Americans, including the authors of this report, reject the welfare state. The model held out by the authors of the report is Texas. That state spent $\$ 192$ per resettled refugee.

"Texas leans more toward the teaching of 'survival skills' - ESL and employment training - and strives to get refugees employed as soon as possible, whether they speak English or not."

It is one thing to have an ideological bias on the basis of which one derives conclusions deformed by the bias. It is another thing to distort legislation. As the report interprets the American Refugee Act of 1980, employment training and placement are to be made available " in order to achieve economic self-sufficiency among refugees as soon as possible." In fact, a state must, as a condition for receiving refugee assistance, submit to the Director of Refugee Resettlement a plan which provides:

“(a) a description of how the state intends to encourage effective refugee resettlement and to promote economic self-sufficiency as quickly as possible;

(b) a description of how the state will ensure that language training and employment services are made available to refugees receiving cash assistance."

There is no phrase "in order to" connecting effective refugee resettlement and the speed of economic self-sufficiency. Effective refugee resettlement is not defined in terms of the speed of obtaining economic self-sufficiency, but conjoined with it. Effective refugee resettlement does not mean getting a refugee $a$ job as soon as possible to get the individual off the state dole. Rather, the intent is to make the refugee economically selfsufficient and effectively resettled - the latter presumably including adequate language training and job training to make the most of the refugee's talent as well as providing opportunities for social adjustment. That, of course, is why the second clause indicates that the goals of both effective resettlement and speedy economic self-sufficiency require language training and employment services - the latter including training and not just job assignments. Thus, when the report states that, "California's approach to the provision of social services to refugees is if conflict with the provisions of the Refugee Act of 1980", one can only conclude that California's interpretation of the Act conflicts with the authors' very biased and self-evidently deformed reading of the same Act. For example, the monies expended directly on social services may be a more reliable indicator of actual dependency. In this case, the gross expenditure for social services declined in the last three years by almost one-third while the total refugee population increased by about $50 \%$; the actual cost per refugee of social services was reduced by over $50 \%$.

The report also draws conclusions unsupported and, I might add, unsupportable by the data. For example, the report implies that perhaps the greatest factor in secondary migration and dependency rates is the high level of cash assistance available in some states. The basis of this evidence is that California, with the second highest per refugee assistance program $(\$ 1,233$ per refugee) has the largest refugee population $(193,841)$ and the highest ratio of refugees to population (1:122). (Washington's is higher $\$ 1,675$ per refugee.) But Texas, with the lowest per capita assistance program, has the second largest number of refugees $(51,932)$ and stands 8th in ratio of refugees to population $(1: 274)$. If the report's claim was true, one would expect Texas to be at the bottom of the list of numbers of refugees and ratio of refugees to population. Since Illinois and Pennsylvania are in the middle of the list of ratios of refugees to population but relatively high in the cost per refugee resettled ( $\$ 940$ for Illinois; $\$ 631$ for Pennsylvania), one finds it difficult to detect the degree of correlation between refugee assistance and refugee resettlement patterns let alone a conclusion that this is the single most important factor.

One more item makes the whole interpretation of data obviously incorrect. Alaska and Vermont provide the highest monthly welfare support ( $\$ 746$ for Alaska; $\$ 587$ for Vermont), yet Alaska has the lowest refugee population (461) and Vermont has the lowest ratio of refugees to population $(1: 1,699)$. One suspects that weather, job availability, previous patterns of migration, the location and strength of VOLAGs (the 15 national voluntary agencies), and family reunification may be equally or more important factors than the amount of social assistance available in the particular state. There are simple statistical correlation tests which are standard in sociological methodology which are not used in this report.

The report's ideological bias, distortion of legislation, misuse of statistics all pale into insignificance when the authors' attitudes to rights of refugees are revealed. The report deplores regulations which permit refugees freedom of movement within the United States. This report is not only opposed to allotting adequate monies for resettlement; it endorses state intervention into freedoms, including one of the most basic freedoms - the freedom to move - an ironic opposition in a report on refugees.

The complaints about the vacant position of the U.S Coordinator for Refugee Affairs from January 1981 to October 1981 and the lack of staffing are mainly concerned with the inadequate monitoring functions, not its assistance role. The report concludes, “ORR's inability to demonstrate the effectiveness of social service programs in expediting the refugees' attainment of self-sufficiency is considered to be a major factor in the cutback of social services in the FY 1983 budget." The authors want it both ways. ORR did not have funds, so it did not monitor well. Because it did not monitor the goal of self-sufficiency, it did not obtain funds. Since the report is guilty of almost every other illogical error, why shouldn't it engage in circular arguments?

The fact, which the Congressional and the Governors' reports both noted, is that funds were not forwarded to states. The federal government, through long delays, disrupted the programs, the administration and the planning. Questions must be raised about the contrast between the lofty ideals of the written 1980 legislation and the economic, executive and administrative policies which undercut the intent and implementation of that legislation.

The analysis evades this issue. Further, an opportunity to learn and become informed has been missed. Perhaps VOLAGs, handling resettlement under contract, deform and distort assistance and use previous refugees as sponsors as an easy way out of ensuring proper resettlement. Also, it may be true that ESL training linked to employment is more effective, but would you trust this conclusion when it is derived from such biased analysis?

\section{Forthcoming . . . Canada's Restrictive Refugee Admission Practices.}




\section{Resettling Hmong in French Guyana}

$A \boldsymbol{n}$ original experiment has been conducted by France in the shape of schemes for resettling groups of refugees in a rural environment. This rural resettlement scheme has been introduced in French Guyana in South America. Guyana, with its low population density and its climate relatively similar to that of Southeast Asia, fulfilled conditions favourable to the resettlement of Hmongs in the same living conditions as they had known in their home country of origin.

In October 1977, 500 Hmongs were settled in several stages at the locality of Cacao. The refugees built their houses themselves. A village has been functioning for the past two years, with a daily allowance of
40 French francs per head being paid by the Directorate of Health and Social Action of the département. This allowance has made it possible to provide food, the staff necessary for the centre and part of the expenditure involved in clearing land and putting it under cultivation. The community has in the meantime become self-sufficient in food and in the spring of 1980 it set up a co-operative composed exclusively of Hmongs. In 1981, Cacao had a total population of 618 persons including 118 young children born since 1977 .

A second settlement of 400 Hmongs was established at Mana in Guyana in October 1979. During the initial phase, some houses, an infirmary and an infant school were built. A building to house the co-operative is in the process of construction. An initial crop of rice was harvested in 1980 , and the local community has attained self-sufficiency in fruit and vegetables.

In 1979, Cacao harvested as much rice as the whole of Guyana. The two villages will shortly be able to feed the entire population of this département which used to import more than $95 \%$ of its food.

(From Council of Europe, July 26, 1982 Steering Committee for Social Affairs CDSO. "Social Situation and Social Measures Concerning People Seeking Political Asylum or Having Status in the Member States of the Council of Europe," by Reinhard Lohmann.)

\section{Refugee Resettlement in Europe \\ Excerpts from a report for the Council of Europe1}

In Europe it is generally speaking the governments which meet the financial costs involved in the reception and resettlement of refugees. The majority of countries place refugees in provisional accommodation centres for periods of 3 - 12 months; in other cases the Canadian pattern is utilized - after only a few days refugees are directed to their final destination to flats or to private sponsors until independent housing is found.

$$
* * * *
$$

\section{Switzerland}

In Switzerland, the social bodies responsible for the reception of refugees and the initial measures to resettle them call upon the services of groups of four to ten voluntary workers to assist the refugees in the resettlement process and maintain regular contacts with them. It is the primary task of these groups of voluntary workers to help refugees find independent accommodation, settle into it, find $a$ job and enrol their children at a school and at the same time to introduce them to their neighbours and to the administrative authorities with which they will have to deal.

Does this seem similar to the proposals to integrate government-assisted resettlement and private sponsorship?

$$
* * * *
$$

\section{Denmark}

In Denmark, refugees enjoy rent-free accommodation from the moment of their arrival, in the same conditions as Danes who are temporarily without earnings.

\section{Federal Republic of Germany}

In the Federal Republic of Germany 6 months after their settlement in independent housing, the refugees will be entitled to subsidised housing

As soon as they arrive, refugees can attend free courses in German.

Foreign refugees who wish to work immediately after completion of a language course will receive during their linguistic training (nine months) maintenance assistance, training fees including materials, commuting expenses, health and accident insurance, and, in the case of any non-local accommodation necessary, also the cost of lodging and extra cost of board.

Foreign refugees who do not wish to work (housewives, pensioners, etc) are paid the cost of the linguistic training and of commuting during the period of the language course (300-800 hours).

Foreign refugees up to 35 years of age who wish to begin an educational or vocational training course after completion of the linguistic training receive the same allowances as under (a) during the period of the language course (up to 48 months).

$$
* * * *
$$

\section{Netherlands}

The Netherlands Government spends each year an average of $\mathrm{FL}$ 32,000 per refugee for help and resettlement (more than 65,000 French francs or $\$ 13,000$ Canadian dollars). A certain proportion of new dwellings must be allocated to refugees.

\section{Sweden}

In Sweden, children who had to interrupt their schooling when fleeing their countries are given an opportunity to continue their education.... The national system of leave for study is also available to refugees.

$$
\text { **** }
$$

\section{Belgium}

In Belgium, UNHCR representatives appraise the legitimacy of the motives of asylumseekers after the Ministry of Justice decides on admissibility.

\section{Austria}

Austria does not allow access to the labour market for asylum seekers. (There were 5,627 cases in 1979.)

\section{Europe in General}

In order to forestall the many abuses of the rules on asylum for persons persecuted on political, religious and racial grounds, it is proving necessary for European countries to take all appropriate steps to reduce the chances of misuses and thus to protect and indeed reinforce the right of asylum for those who are in the most urgent need.

$$
* * * *
$$

1. Social Situation and Social Measures Concerning People Seeking Political Asylum or Having Refugee Status in the Member States of the Council of Europe. (Activity 6.50.2) July 1982.

\section{Forthcoming ... Unaccompanied Minors in Canada.}

